\title{
economics-of-security.eu
}

Christos Kollias and Stephanos Papadamou

\section{Rogue state behavior and markets: The financial fallout of North Korean nuclear tests}

April 2012

Economics of Security Working Paper 67

This publication is an output of EUSECON, a research project supported by the European Commission's Seventh Framework Programme.

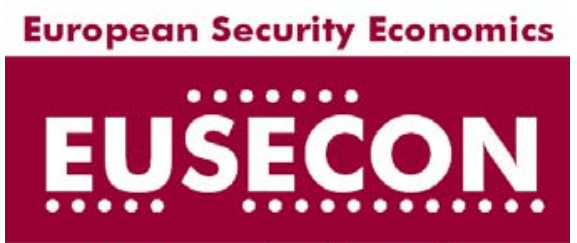

www.economics-of-security.eu

Economics of Security is an initiative managed by DIW Berlin 
Correct citation: Kollias, C. and Papadamou, S. (2012). "Rogue state behavior and markets: The financial fallout of North Korean nuclear tests". Economics of Security Working Paper 67, Berlin: Economics of Security.

First published in 2012

(C) Christos Kollias and Stephanos Papadamou 2012 ISSN: 1868-0488

For further information, please contact:

Economics of Security, c/o Department of Development and Security, DIW Berlin - German Institute for Economic Research, Mohrenstr. 58, 10117 Berlin, Germany.

Tel: +49 (0)30 $89789-277$

Email: eusecon@diw.de

Website: www.economics-of-security.eu 


\title{
ROGUE STATE BEHAVIOR AND MARKETS: The FinANCIAL FAllout OF NORTH KOREAN NUCLEAR TESTS
}

Christos Kollias*

Department of Economics, University of Thessaly, Volos, Greece

\begin{abstract}
Financial markets react to major political events. The two nuclear tests conducted by North Korea in 2006 and 2009 were a sober confirmation of the nuclear weapon capacity of this state with the concomitant potential security threat this posed for the stability of the greater region. We examine how ten regional stock exchanges and currency markets reacted to this security development and these two specific events. The results, although not uniform across all countries and markets, revealed a greater adverse effect in the case of the second of the two tests. On the whole, the adverse effects on the stock exchanges were short lived.
\end{abstract}

Key words: nuclear tests and financial markets; event studies; GARCH models; quantile regression J EL classification: $\mathrm{H}_{56}$, G1, G14

Acknowledgments: This paper is part of the research project "A New Agenda for European Security Economics", funded by the 7th Framework Programme, to which the authors acknowledge financial support.

*Correspondding author: kollias@uth.gr 


\section{INTRODUCTION}

In 2010 tensions in the Korean peninsula rose to very high levels when both North and South Korea were brought to the brink of a potentially large scale military confrontation while third parties and allies of the South and in particular the United States, also mobilized their military assets in the area. The military escalation of 2010 was by no means an uncommon situation for the region. Although the July 1953 armistice brought an end to the Korean War (1950-1953); the area has ever since been continuously characterized by friction and tension between the North and the South. Bellicose rhetoric, saber rattling, artillery exchanges, incursions, skirmishes and armed engagements along the $38^{\text {th }}$ parallel and the buffer zone established after the cessation of hostilities, have invariable been the order of the day despite lulls of rapprochement and improvements in the relations not only between North and South Korea but also between the Democratic People's Republic of Korea (DPRK) and other global or regional players such as the United States and Japan.

Given the history of the division of the Korean peninsula, the military dimension is an omnipresent factor that shapes relations and events in the area (Bae, 2004; Smith, 2006). As Bae (2004) points out, the appreciable headway made in areas such as the economic relations between the two Koreas, has never lifted the threat of a full scale armed confrontation with the South fearing a surprise pre-emptive attack by the North Korean regime. In fact, North Korea has constantly presented its neighbors in the region as well as the West in general, with a major political and military challenge. The DPRK's nuclear aspirations have always been a major source of security risk 
for the region (Smith, 2006). The two nuclear tests of $9^{\text {th }}$ October 2006 and $25^{\text {th }}$ May 2009 were a sober confirmation of the North's nuclear capacity with the concomitant policy response options for deterrence in the context of nuclear proliferation (Arce and Sandler, 2009). Although by no means technologically comparable to the West's nuclear arsenal, the mere fact that the North Korean regime had a proven crude nuclear capability that could potentially use it, added a qualitatively different dimension in the security equation of the region.

As a growing number of studies has shown, from the markets' perspective, major political developments, such as the two nuclear tests conducted by North Korea, represent external events that can directly affect risk premia and investors' sentiment and as a consequence lead to increased volatility, hence exerting an adverse impact on asset valuation, investment decisions and portfolio allocation (inter alia: Chesney et al. 2011; Drakos, 2010; Wisniewski, 2009; Corallo, 2007; Chan and Wei, 1996). Within the thematic focus of such studies, this paper sets out to examine how markets in the greater region reacted to the two tests that confirmed North Korea's nuclear capability and hence affected the security environment of the region. The general indices examined are: Shanghai Composite (China), Hang Seng (Hong Kong), Bombay Sensex (India), Jakarta Composite (Indonesia), Nikkei 225 (Japan), Kospi Composite (S. Korea), Kuala Lumpur (Malaysia), PSE Composite (Philippines), Straits Times (Singapore) and the Taiwan Weighted (Taiwan). Furthermore, apart from the stock exchanges, the potential impact the two nuclear tests had on the currency markets is also investigated. 


\section{Political Events ANd Markets}

Ample evidence suggest that economic activity is affected, through a number of channel,s by political news and events such as intra and interstate conflict and war, domestic and/or international political tension and instability, terrorist activity (inter alia: Gaibulloev and Sandler, 2008, 2009; Blomberg and Hess, 2002; Vuchelen, 2003; Chan and Wei, 1996; Asteriou and Siriopoulos, 2003). In particular, the reaction of markets to security events and political developments, including war, military tension, civil strife, terrorism, is an issue that has attracted growing attention in the relevant literature (inter alia: Guidolin and La Ferrara, 2010; Drakos, 2010, 2011; Schneider and Troeger, 2006; Kollias et al. 2010, 2011; Choudhry, 2010; Corallo, 2007). As, among others, Frey and Kucher (2000, 2001) observe, markets echo and reverberate such major political events and incidents. Political and economic news, elections, policy shifts, political instability, coups, terrorist attacks, even major sports events can affect investors' sentiment, market agents' asset valuations, market and country risk perceptions and portfolio allocation decisions (inter allia: Chesney et al. 2011; Desbordes, 2010; Amihud and Wohl, 2004; Siokis and Kapopoulos, 2007; Vuchelen, 2003; Bilson et al. 2002; Drakos, 2010; Wisniewski, 2009). As Bialkowski et al. 2008 note, markets can be unsettled by important political events and changes due to the risk and uncertainty they may potentially represent while their performance may also appreciably vary depending on the orientation of the incumbent government. In particular, rare events such as the two North Korean nuclear tests examined here, affect the political risk component of portfolio allocation decisions. Bilson et al. (2002) point out that 
the concept of political risk is quite broad, multidimensional and difficult to quantify. Nevertheless, the risk stemming from political acts, actions and policies by governments or state agents can affect and threaten the expected returns on investment or the reverse, i.e. improve investment prospects and opportunities and hence positively affect stock markets (Wisniewski, 2009; Chan and Wei, 1996).

Given the global nature of financial markets and their close ties and interrelationships, an increase in the risk emanating from the actions (or expected actions) of a government or state can bring about noteworthy changes and shifts in equity markets, in the cross country correlation of assets, in portfolio allocation and diversification. Such risks are particularly present in developing areas of the world where states are, in comparative terms, more prone to political instability, or in regions where regional security and stability may be threatened by bilateral friction and tension between regional rivals (for example India and Pakistan) or the unilateral actions of a rogue state; in this case the North Korean regime. As, among others, Kollias et al. 2010 point out, the effects that political events may exert vary across markets, countries and through time. Their impact depends upon a variety of factors such as for instance the severity of the specific event, its expected duration and final outcome and whether or not was anticipated by market agents. For example, although the threat of terrorism is to some extent omnipresent, terrorist attacks are unannounced and unexpected when they actually occur. Thus, they can act as exogenous shocks to markets. As it has been argued, investors can hedge against expected events but not so when it comes to events such as a terrorist attack (Drakos, 2010, 2011; Kollias et al. 2010; Arin et al. 2008). On the other hand, Amihud and Wohl (2004) have argued that, whenever major 
events such as a war are preceded by strong expectations for their occurrence, for instance an official statement of firm intention and commitment, markets will invariably tend to incorporate this information in the prices before such events actually take place. This observation is particularly relevant in our case since the first of the two nuclear tests was announced in advance. Hence, it was expected, whereas the second was not. Furthermore, as political events, for instance an armed conflict or war, unfold; market agents will adjust their position depending on the anticipated result of the conflict as this is determined by various incidents during the military operations that can affect the course and the final outcome of the fighting (Corallo, 2007; Kollias et al. 2010; Choudhry, 2010). For example, in the case of the 2008-09 Israeli military offensive in the Gaza strip, Kollias et al. 2010 report findings that point to a changing behaviour by market participants in the Tel Aviv stock exchange as the offensive unfolded and the probability of a successful conclusion both in military and political terms increased. Frey and Kucher (2000, 2001) find evidence indicating that major events that shaped the course of World War II have left an identifiable imprint on bond markets. Similar findings for World War II events that are historically considered as important turning points are reported by Choudhry (2010). Results by Amihud and Wohl (2004) also show that markets, during the second Gulf War, adjusted their behaviour to the probability of Saddam's fall from power and hence the final outcome of the war.

Within the broader context and spirit of the aforementioned studies and findings, the two nuclear tests conducted by the North Korean regime, added a further risk dimension in the security equation of the region and the 
concomitant risk profile of the area. As already noted earlier, the fact that North Korea was for some years pursuing a nuclear military capability was well known. The North's withdrawal from the Nuclear Non-Proliferation Treaty in March 1993 and the nuclear crisis that ensued, may be considered as the formal announcement, urbi et orbi, of the beginning of the North's efforts to acquire nuclear weapons which clearly had strategic implications for policy response options in view of the nuclear proliferation threat it posed (Arce and Sandler, 2009). The signing of the Agreed Framework in October 1994 between DPRK and the USA ended the crisis at the time but not the North's nuclear efforts. The two tests on the $9^{\text {th }}$ October 2006 and $25^{\text {th }}$ May 2009 were in a sense proof of the successful culmination of these efforts and signalled the North's official accession to the club of countries that posses nuclear weapons. The now proven crude nuclear capability of DPRK, added a qualitatively different dimension in the security equation of the region given the characteristics and aggressive behaviour of the North Korean regime. Perhaps, before we proceed with the empirical examination of how markets in the region reacted to this new development, it is worth mentioning a significant difference between the two tests that will be incorporated in the empirical investigation that follows. The first of the two tests, i.e. the one that took place on the $9^{\text {th }}$ October 2006 was announced in advance by North Korea. The official announcement was made a few days earlier on October, $3^{\text {rd }}$. The second test, three years later on $25^{\text {th }}$ May 2009, was not announced in advanced. Thus it may be treated as a totally unexpected event from the markets' perspective. 


\section{DAta And Methodology}

Our sample consists of daily stock market data from the stock exchanges of ten countries in the region: Japan, Hong Kong, S. Korea, China, Taiwan, Singapore, India, Indonesia, Philippines and Malaysia. The time period ranges from 01/01/1998 to 01/01/2010 and includes the dates of the two nuclear tests in question: 9/10/2006 and 25/5/2009. As already pointed out, the first of the two tests was announced in advanced (3/10/2006). Given this important qualitative difference, for the purposes of our analysis the date of the official announcement is taken to be the event day since it is then that all agents involved were informed of the North's intention to conduct a nuclear test that was proof of the nuclear capability now possessed by the DPRK. This clearly is not the case for the 2009 test that was unannounced. Hence the actual day it took place is taken as the event date. An interesting byproduct of the analysis that follows will be to see whether market reaction differed in the case of the latter, i.e. the unannounced, vis-à-vis the announced nuclear test.

In line with previous studies such as for instance Arin et al. (2008), Kollias et al. (2010), we assume that any market reaction to the event starts on the first day after the event itself. Thus, in order to test the significance of the reversal effect, we examine the first three trading days after each nuclear test or the announcement in the case of the first. To test the null hypothesis and to estimate the impact that the two events had on stock returns, we adopt a similar methodology used in previous event studies (inter allia: Kaplanski and Levi, 2010; Kamstra, et al. 2003; Brown and Warner, 1980, 1985). Assuming that investors do not hedge against exchange rate risk, the conditional version 
of the world CAPM augmented for several known anomalies in financial markets implies the following behaviour for returns:

$$
R_{t}=\gamma_{0}+\sum_{i=0}^{1} \gamma_{1, i} R W_{t-i}+\sum_{i=1}^{5} \gamma_{2, i} R_{t-i}+\sum_{i=1}^{4} \gamma_{3, i} D_{i, t}+\gamma_{4} \operatorname{Tax}_{t}+\sum_{j=1}^{2} \sum_{i=1}^{3} \gamma_{5, j, i} D N_{j, i, t}+\sum_{i=1}^{2} \gamma_{6, i} D L B_{i, t}+\varepsilon_{t}
$$

where $R_{t}$ is the daily rate of return on the relevant stock price index, $\gamma_{o}$ is the regression intercept. In order to account for any possible serial correlation, since previous studies have found a weak tendency for movements in aggregate US stock returns to persist (see for example Schwert, 1990a, 1990b), $\mathrm{R}_{\mathrm{t}-\mathrm{i}}$ is the ith previous day rate of return included in the model. We look at as many past returns as are necessary to guarantee that all significant serial correlations have been accounted for. $\mathrm{RW}_{\mathrm{t}}$ denotes the return on World Market Portfolio proxied by Stoxx Global 1800 index that consists of 600 stocks from Europe, 600 stocks from USA and 600 from Asian markets ${ }^{1}$. The actual empirical specification we used is rather more flexible, allowing not only for contemporaneous sensitivity but also for a dynamic relationship between $R_{t}$ and $R W_{t}$ where lagged values of order one of the latter will be included in order to capture time lags between Asian and rest of the world markets. We also allow for the "weekend effect" or "Monday effect" (inter allia: Cho et al. 2007; French, 1980; Schwert, 1990a). Since this may bias the regression results dummy variables $D_{i}, i=1, . ., 4$, are included in the estimations. Moreover, we add a dummy variable for the first five days of the taxation year $\left(\mathrm{Tax}_{\mathrm{t}}\right)$ in order to capture any January effect (see for instance Keim, 1983; Dyl and Maberly, 1992). The $\mathrm{DN}_{\mathrm{j}, \mathrm{i}}(\mathrm{j}=1,2$ and $\mathrm{i}=1 ; 2 ; 3)$ stands for

\footnotetext{
${ }^{1}$ The relevant source of the data is: ww.stoxx.com
} 
possible effect and reversal effect variables for the days after the two nuclear tests $(\mathrm{j}=1$ corresponds to $03 / 10 / 2006$ and $\mathrm{j}=2$ to $25 / 5 / 2009$ ). Furthermore, given the significance of the Lehman Brothers default announcement on the world economy we also included relevant dummy variables for the days related to the event announcement and one day after to allow for the time lag between Asian and rest of the world markets. Since we are dealing with daily returns on consecutive days, it was felt that we must control for known anomalies to ensure they do not contaminate the results. Based on equation (1) estimated parameters, the main research questions tested here can be summarised as follows:

$\mathrm{H}_{1}$. We first test the joint hypothesis of both the event effect and the reversal effect asserting that there is a below average rate of return $\left(\gamma_{5, j, 1}<0\right)$ on the first day after the event (or the announcement of the event) and an above average rate of return $\left(\gamma_{5, j, 2}>0\right)$ on the reversal day immediately afterwards.

$\mathrm{H}_{2}$. Given the North-South tension, does the South Korean stock exchange present the larger - in absolute terms - event day coefficient vis-à-vis other the stock markets?

$\mathrm{H}_{3}$. Does geographic proximity determine the magnitude and the persistence of any effect?

$\mathrm{H}_{4}$. Was there any significant observable difference in how small and large capitalisation markets reacted?

$\mathrm{H}_{5}$. Did the reaction differ in the case of the announced nuclear test visà-vis the unannounced?

$\mathrm{H}_{6}$. Were there any differences in the reaction by currency markets compared to the stock markets' reaction? 
To allow for the possibility that a few extreme observations affect the results, we estimate a quantile regression (QR), introduced by Koenker and Bassett (1978). Quantile regressions (QR) are not as sensitive to extreme observations as the typical OLS regression can be (see for instance Portnoy and Koenker, 1997; Koenker and Hallock, 2001). Thus, instead of estimating the conditional mean via the OLS method, the QR method is employed to estimate conditional median in our case. The linear regression model takes the form:

$$
y_{t}=\mathbf{x}_{\mathbf{t}} \boldsymbol{\beta}+\varepsilon_{t}
$$

Where $\mathbf{x}_{\mathbf{t}}$ is a row vector of explanatory variables with first element equal to 1 ; $e_{t}$ is an error term independent of $\mathbf{x}_{\mathbf{t}}$; and $\boldsymbol{\beta}$ is a vector of the parameters. The conditional quartile function can be written as

$$
Q(\psi)_{t}=\mathbf{x}_{\mathbf{t}} \boldsymbol{\beta}(\psi)
$$

Where $\boldsymbol{\beta}(\psi)$ is a vector of parameters dependent on $\psi$. In our case the $\psi$ equals to 0.50. Koenker and Basset (1978) define the $\psi$-th regression quartile $(0<\psi<1)$ as any solution $\boldsymbol{\beta}(\psi)$, to the quantile regression minimization problem:

$$
\min _{\boldsymbol{\beta}}\left[\sum_{t: y_{t}>\mathbf{x}_{\mathbf{t}} \boldsymbol{\beta}} \psi\left|y_{t}-\mathbf{x}_{\mathbf{t}} \boldsymbol{\beta}\right|+\sum_{t: y_{t}<\mathbf{x}_{\mathbf{t}} \boldsymbol{\beta}}(1-\psi)\left|y_{t}-\mathbf{x}_{\mathbf{t}} \boldsymbol{\beta}\right|\right]
$$

In order to take into account a possible conditional heteroskedasticity, we also assume time-varying volatility and employ a Generalised Autoregressive Conditional Heteroskedasticity $\operatorname{GARCH}(1,1)$ model (Engle, 1982; Bollerslev, 1986). Therefore a model of the following form for the mean and the variance is estimated: 


$$
\begin{aligned}
R_{t} & =\gamma_{0}+\sum_{i=0}^{1} \gamma_{1, i} R W_{t-i}+\sum_{i=1}^{5} \gamma_{2, i} R_{t-i}+\sum_{i=1}^{4} \gamma_{3, i} D_{i, t}+\gamma_{4} \operatorname{Tax}_{t}+\sum_{j=1}^{2} \sum_{i=1}^{3} \gamma_{5, j, i} D N_{j, i, t}+\sum_{i=1}^{2} \gamma_{6, i} D L B_{i, t}+\varepsilon_{t} \\
\varepsilon_{t} & \sim N\left(0, h_{t}\right) \\
h_{t} & =\alpha_{0}+\alpha_{1} \varepsilon_{t-1}^{2}+\beta_{1} h_{t-1}
\end{aligned}
$$

Where all variables are defined as previously mentioned and $\varepsilon_{t}$ is the error term with conditional mean zero and conditional variance $h_{t}$. The estimation of the equation of interest using quartile regression and GARCH modelling for volatility, may be viewed as robustness checks.

Finally, as already pointed out in the research questions outlined above, the effect of the two North Korean nuclear tests on currency markets was also investigated. So far, we advocate that the additional country and region risk the two nuclear events may potentially represent, affect investors sentiment, their risk assessment and hence their investment decisions. However, increased risk and uncertainty may lead market participants and investors to seek to invest in alternative safer assets. To test whether there was also a flight to safety by shifting investments from risky assets to less risky assets we also test the effect of the nuclear tests in the exchange rates of US dollar. In other words, it is possible that international investors after each nuclear test may decide to sell Asian currencies for the safer, in such circumstances, US dollar. To this end, using an event study analysis we examine the reaction of the foreign exchange markets to the two nuclear tests.

To start with, the rate of change of the US dollar exchange rates is calculated on a daily frequency by taking first differences of the logarithmic levels. The US dollar is expressed in the relevant Asian currency in each of the countries used in the study. For our purposes here, the daily excess returns for the rate of change in foreign exchange rates are measured by the mean- 
adjusted-returns approach (MacKinlay, 1997). That is, for each day at, and following, the event, we computed:

$$
A R_{t}=R_{t}-\bar{R}
$$

where $A R_{t}$ is the abnormal rate of change for the US dollar versus the Asian currency at time $\mathrm{t}, R_{t}$ is the actual observed rate of change for the exchange rate, and $\bar{R}$ is the mean of this daily rate of changes in the $(-30,-11)$ estimation period (see for instance Chen and Siems, 2004; Kollias et al. 2010, 2011).

$$
\bar{R}=\frac{1}{20} \sum_{t=-30}^{-11} R_{t}
$$

Firstly, the event-day abnormal returns are calculated. Secondly, longer event windows were examined by computing the cumulative average abnormal returns (CARs) two $(t=2)$ to six days $(t=6)$ following the event. The cumulative abnormal returns (CARs) were estimated using the following equation:

$$
C A R_{t}=\sum_{t=T_{1}}^{T_{2}} A R_{t}
$$

where $T_{1}$ is the event day and $T_{2}$ is consequently $1,2,3,4$, and 5 days after the event.

\section{EMPIRICAL FINDINGS AND DISCUSSION}

The empirical findings of the estimations are presented in Tables 1, 2 and 3. In particular, the results for each of the ten stock markets indices - i.e. Shanghai Composite (China), Hang Seng (Hong Kong), Bombay Sensex (India), Jakarta Composite (Indonesia), Nikkei 225 (Japan), Kospi Composite (S. Korea), Kuala Lumpur (Malaysia), PSE Composite (Philippines), Straits 
Times (Singapore), Taiwan Weighted (Taiwan) - are shown in Table 1. We start with the first of the two nuclear tests that is the one that took place on the $9^{\text {th }}$ October 2006 but was announced in advance on October, $3^{\text {rd }}$, the latter being the date taken as the event date in the relevant tests as already pointed out. As it can be seen from Table 1, with the exception of three stock indices in Hong Kong, Singapore and Indonesia, the first day coefficient is negative and statistically significant in all the other stock market indices examined here. Moreover, consistent with our hypothesis, from the seven negatively affected markets, the South Korean KOSPI index presents the larger in absolute terms coefficient (-1.83); a finding clearly attributable to the direct proximity of South Korea and the fact that this development added a new and qualitatively different dimension to the South's security equation. The second day coefficient is positive and statistically significant in the case of India, Japan, Taiwan and the Philippines. It would appear that in all these cases the first day negative effect is apparently offset by the second day reversal effect, suggesting only a short term impact of the first nuclear test on these stock markets. Again, as one would intuitively expect, the notable exception is the Korean market where the reversal effect is not immediate. Worth noting are the cases of the Indonesia and Hong-Kong markets where the $\gamma_{5,1,2}$ coefficient is negative and statistically significant that could tentatively be interpreted as suggesting a delayed reaction. However, this effect is offset by a positive coefficient in the third day following the announcement.

Table 1 here 
Turning to impact of the second and unannounced North Korean nuclear test (25/5/2009), it appears that the negative effect is more significant in case of India and South Korea. Also, the stock market in Singapore presents a negative and statistically significant first day reaction compared to no reaction for the official announcement of the first test. In the case of the Nikkei-225 index, the rebound takes more than one day compared to Taiwan, Philippines, India and China where markets rebounded in one day (Table 1). An interesting observation is that the reaction of the markets in question to the Lehman Brothers default announcement is appreciably greater in absolute terms, with the exception of Singapore. It appears that adverse financial news yield a greater reaction compared to the impact major political incidents such as the two nuclear tests examined here with the effects being rather transitory and short lived.

An inspection of the results for the various control variables (i.e. the world market index, serial correlation, the day of the week effect and tax effects) reveals the following: (a) The coefficient of the world market index is statistically significant in all stock markets. However, in some of them the lag variable of the world market index has a stronger effect on the markets studied a finding that can probably be attributed to non-synchronous trading among Asian markets and the rest of the world. (b) The serial correlation coefficients are significant mostly in the one period lag for the majority of the indices. In case of Japan, Korea, Taiwan and China the coefficient $\gamma_{2,1}$ is negative and statistically significant while for lower capitalization markets this coefficient is positive and statistically significant. Moreover, in some cases, statistically significant coefficients are found for period lags two, three and four (see Table 2). When it comes to the week day dummies, the Monday 
coefficient, that is negative and statistically significant in the case of Singapore and Taiwan, becomes less significant when the heteroskedasticity effect and extreme values are taken into account. Finally, on the basis of the results reported in Tables 1 and 2, there is some evidence that the Tuesday coefficient is negative and statistically significant, in cases of Indonesia, Malaysia and Taiwan.

Table 2 here

The results reported in Table 2, where the QR and a GARCH model are employed, reveal that the findings concerning the effects of the two nuclear tests remain intact and this is strongly suggesting that the results concerning the impact of the nuclear tests are not spurious. The first day following the event (or the announcement of it in the case of the first test) coefficient is negative and statistically significant in the same cases just as in Table 1. A stronger effect is found to be the case for the stock markets of Korea, India and Singapore. In the case of Japan the rebound of the Nikkei index is achieved in two days rather than in one.

\section{Figure 1 here}

Finally, we turn to the currency markets and the results shown in Figure 1 where the event study findings for the relevant currencies versus the US dollar (i.e. the cumulative abnormal returns and the t-statistics for the 1-, to 6-day event windows) are shown. Overall, it appears that the findings are not uniform across both nuclear tests. On the one hand, in the case of the first 
and announced nuclear test the effects on the currencies are generally weak. However, worth noting is that only the five (for the Korean Won and the Philippines Pesos) and six-day CARs (for the Korean Won, the Philippines Pesos and the Japanese Yen) are positive and statistically significant. A tentative explanation could be that the currency markets were more affected by the test itself (9/10/2006) rather that the announcement of it (3/10/2006). On the other hand, the effect of the second nuclear test (25/5/2009) is more uniform across currencies. It would appear that a flight to the relatively more secure US dollar is in fact the case for the majority of currencies. The more persistent effect can be seen in the following exchange rates: IDR/USD, PHP/USD, SGD/USD, JPY/USD and KOR/USD. However, this turn to the US dollar is not immediate over the event day but rather there appears to be an increasing trend toward the US dollar over the next days.

To conclude the discussion, if an overall summing up of the results is attempted, it appears that in the case of the first nuclear test that was preceded by an official announcement by the DPRK authorities the effect on the stock markets' indices examined here were negative and short lived (mostly one day) in seven out of ten cases. Furthermore, this first day negative reaction was offset by the second day rebound in the majority of them. Weak were the effects observed in the currency exchange markets with evidence of selling local currency for the US dollar only in the case of the Korean Won and the Philippines Pesos. In the case of the second nuclear test, where there was no previous announcement of it, the reaction is more negative for Korea, India and China and similar to the Lehman Brothers default announcement for these markets. In contrast to the first nuclear test, the Singapore market also appears to have been affected. Additionally, the reported results seem to 
indicate that the second and unannounced test appears to have triggered a flight to safety in foreign exchange markets with an increasing upward trend for the US dollar for the days following the event. In terms of duration, the effect the nuclear tests had on currency market can be characterized, in comparative terms, as more significant and longer lasting.

\section{Concluding Remarks}

As a plethora studies have shown, financial markets react to major political events such as military tension, armed conflict, civil strife and terrorism. The two nuclear tests conducted by the North Korea regime were a sober confirmation of its nuclear weapon capacity with the concomitant potential security threat this poses for the stability of the greater region given the often quite aggressive military behaviour of the DPRK. This paper set out to examine how ten stock exchanges and currency markets in the region reacted to the two tests. The results, although not uniformed across all countries and markets, revealed a greater adverse effect in the case of the second of the two tests. The qualitative difference between the two events being that the first was announced whereas the second was unexpected. This seems to suggest that the prior announcement provided ample time for markets to evaluate and absorb in a more efficient and sober manner the news whereas the unannounced second nuclear test was more of an exogenous shock that markets did not expect and hence rattled them more.

Of the ten countries and markets examined here, the most affected was South Korea. This of course is by no means a surprising finding given that South Korea is the country that is faced with the direct security risk the DPRK 
represents and has on a regular basis been at the receiving end of the North's military aggressiveness. Perhaps an interesting extension to this study would be to develop a time-series index that quantifies and tracks the fluctuation of tension in the bilateral relations of the two Koreas and examine how this is echoed in the Seoul stock exchange and the Korean Won currency market. Clearly of course, such an exercise with a Korean peninsula tension index can also be attempted for other regional markets as well, in order to capture the wider regional repercussions. 


\section{References}

Amihud, Y. and A. Wohl, 2004, Political news and stock prices: the case of Saddam Hussein contracts. J ournal of Banking and Finance 28, 11851200.

Arce, D. and T. Sandler, 2009, Deterrence: credibility and proportionality, Economics and Politics 21, 384-408.

Asteriou, D. and C. Siriopoulos, 2003, The role of political instability in stock market development and economic growth: the case of Greece, Economic Notes 29, $355-374$.

Bae, J., S. 2004, An empirical analysis of the arms race between South and North Korea. Defence and Peace Economics 15, 379-392

Bialkowski, J., K. Gottschalk and T. Wisniewski, 2008, Stock market volatility around national elections. J ournal of Banking and Finance 32, 19411953

Bilson, C., T. Brailsford and V. Hooper, 2002. The explanatory power of political risk in emerging markets. International Review of Financial Analysis 11, 1-27

Blomberg, B. and G. Hess, 2002, The temporal links between conflict and economics activity. J ournal of Conflict Resolution 46, 74-90

Bollerslev, T., 1986. Generalized autoregressive conditional heteroskedasticity. J ournal of Econometrics 31, 307-327.

Brown, S. and J. Warner, 1980. Measuring security price performance. J ournal of Financial Economics 8, 205-258. 
Brown, S. and J. Warner,, 1985. Using daily stock returns: the case of event studies. J ournal of Financial Economics 14, 3-31.

Chan, Y-C. and J. Wei, 1996. Political risk and stock price volatility: the case of Hong Kong. Pacific-Basin Finance J ournal 4, 259-275

Chen, A. And T. Siems, 2004. The effects on terrorism on global capital markets. European J ournal of Political Economy 20, 435-446.

Chesney, M., G. Reshetar and M. Karaman, 2011. The impact of terrorism on financial markets: an empirical study, J ournal of Banking and Finance, $35,253-267$

Cho, Y.H., O. Linton and Y. J. Whang, 2007. Are there Monday effects in stock markets? A stochastic dominance approach. Journal of Empirical Finance 14, 736-755.

Choudhry, T., 2010. World War II events and the Dow Jones industrial index. J ournal of Banking and Finance 34, 1022-1031

Corallo, E., 2007, The effect of the war risk: a comparison of the consequences of the two Iraq wars, International Review of Economics 54, 371-382

Desbordes, R. 2010, Global and diplomatic political risks and foreign direct investment, Economics and Politics 22, 92-125.

Drakos, K. 2011. Behavioral channels in the cross-market diffusion of major terrorist shocks, Risk Analysis 31, 143-159

Drakos, K. 2010. Terrorism activity, investor sentiment and stock returns, Review of Financial Economics 19, 128-135 
Dyl, E.A. and E.D. Maberly, 1992. Odd-lot transactions around the turn of the year and the January effect. Journal of Financial and Quantitative Analysis 27, 591-604.

Engle, R.F., 1982. Autoregressive conditional heteroskedasticity with estimates of the variance of U.K. inflation. Econometrica 50, 987-1008.

French, K.R., 1980. Stock returns and the weekend effect. Journal of Financial Economics 8, 55-69.

Frey, B. and M. Kucher, 200o. World War II as reflected on capital markets. Economics Letters 69, 187-191.

Frey, B. and M. Kucher, 2001. Wars and markets: How bond values reflect the Second World War. Economica 68, 317-333.

Gaibulloev, K. and T. Sandler, 2009, The impact of terrorism and conflict on growth in Asia. Economics and Politics 21, 359-383.

Gaibulloev, K. and T. Sandler, 2008, Growth consequences of terrorism in Western Europe. KYKLOS 61, 411-424.

Guidolin, M. and E. La Ferrara, 2010. The economic effects of violent conflict: evidence from asset market reactions. J ournal of Peace Research, 47, $671-684$

Kamstra, M.J., L.A. Kramer and M.D. Levi, 2003. Winter blues: a SAD stock market cycle. American Economic Review 93, 324-343.

Kaplanski, G. and H. Levy, 2010. Sentiment and stock prices: The case of aviation disasters. J ournal of Financial Economics 95, 174-201.

Keim, D.B., 1983. Size-related anomalies and stock return seasonality: further empirical evidence. J ournal of Financial Economics 12, 13-32. 
Koenker, R. and G. Bassett, 1978. Regression quantiles. Econometrica 46, 3350.

Koenker, R. and K.F. Hallock, 2001. Quantile regression. J ournal of Economic Perspectives 15, 143-156.

Kollias, C., S. Papadamou and A. Stagiannis, 2011. Terrorism and capital markets: the effects of the Madrid and London bomb attacks, International Review of Economics and Finance, 20, 532-541.

Kollias, C., S. Papadamou and A. Stagiannis, 2010. Armed conflicts and capital markets: the case of the Israeli military offensive in the Gaza Strip. Defence and Peace Economics 21, 357-365

MacKinley, A. C., 1997. Event studies in economics and finance. Journal of Economic Literature 35, 13-39.

Newey, W.K. and K.D. West, 1987. A simple positive semidefinite, heteroscedasticity and autocorrelation consistent covariance matrix. Econometrica 55, 703-8.

Portnoy, S. and R. Koenker, 1997. The Gaussian hare and the Laplacian tortoise: computability of squared-error versus absolute-error estimators, with discussion. Statistical Science 12, 279-300

Schneider, G. and V. Troeger, 2006. War and the world economy, Stock market reactions to international conflicts. Journal of Conflict Resolution 50, 623-645.

Schwert, G.W., 1990a. Indexes of United States stock prices from 1802 to 1987. J ournal of Business 63, 399-426. 
Schwert, G.W., 1990b. Stock volatility and the crash of 87. Review of Financial Studies 3, 77-102.

Siokis, F. and P. Kapopoulos, 2007, Parties, elections and stock market volatility: evidence from a small open economy. Economics and Politics $19,123-134$.

Smith, C. 2006. North Korea: The case for strategic entanglement, Orbis 50, $343-353$

Vuchelen, J. 2003, Electoral systems and the effects of political events on the stock market: the Belgian case, Economics and Politics 15, 85-101.

Wisniewski, T., 2009. Can political factors explain the behaviour of stock prices beyond the standard present value models? Applied Financial Economics 19, 1873-1884 
TABLES AND FIGURES

Table 1 The effects of nuclear tests on Asian stock markets. Estimation results for equation 1.

\begin{tabular}{|c|c|c|c|c|c|c|c|c|c|c|c|c|c|c|c|c|c|c|c|c|c|c|c|}
\hline \multirow[t]{2}{*}{ Country } & \multirow[t]{2}{*}{ Stock Index } & \multirow[t]{2}{*}{$Y_{0}$} & \multirow[t]{2}{*}{$\mathrm{RW}_{\mathrm{t}}$} & \multirow[t]{2}{*}{$\mathrm{RW}_{\mathrm{t}-1}$} & \multirow[t]{2}{*}{$R_{t-1}$} & \multirow[t]{2}{*}{$R_{t-2}$} & \multirow[t]{2}{*}{$R_{t-3}$} & \multirow[t]{2}{*}{$R_{t-4}$} & \multirow[t]{2}{*}{$R_{t-5}$} & \multirow[t]{2}{*}{ Mon. } & \multirow[t]{2}{*}{ Tues. } & \multirow[t]{2}{*}{ Wed. } & \multirow[t]{2}{*}{ Thurs. } & \multirow[t]{2}{*}{$\begin{array}{c}\text { First } 5 \\
\text { days of } \\
\text { tax year }\end{array}$} & \multicolumn{3}{|c|}{$\begin{array}{c}\text { Post Nuclear Test } \\
\text { Announcement (03/10/2006) }\end{array}$} & \multicolumn{3}{|c|}{\begin{tabular}{|c|} 
Post Nuclear Test \\
Announcement (25/05/2009)
\end{tabular}} & \multicolumn{2}{|c|}{$\begin{array}{c}\text { Lehman Brothers } \\
\text { Default } \\
\text { Announcement }\end{array}$} & \multirow{2}{*}{$\begin{array}{c}\mathrm{R}^{2} \\
\text { F-statistic } \\
\text { (p-value) }\end{array}$} \\
\hline & & & & & & & & & & & & & & & 1st day & 2nd day & 3rd day & 1st day & 2nd day & 3rd day & Event day & 1 day after & \\
\hline \multirow{2}{*}{ China } & Shanghai & -0.00007 & 0.08922 & 0.16362 & \begin{tabular}{|c|}
$\mid-0.16385$ \\
\end{tabular} & -0.04505 & 0.02468 & 0.02650 & -0.01628 & 0.00072 & -0.00064 & 0.00177 & -0.00006 & 0.00460 & -0.00218 & -0.00150 & -0.00047 & -0.00785 & 0.01248 & 0.00303 & \begin{tabular}{|l|}
-0.00203 \\
\end{tabular} & -0.03763 & 0.035454 \\
\hline & Composite & $(0.92)$ & $(0.04)^{* *}$ & $(0.00)^{* * *}$ & $(0.03)^{* *}$ & $(0.12)$ & $(0.31)$ & $(0.25)$ & $(0.40)$ & $(0.51)$ & $(0.56)$ & $(0.08)^{*}$ & $(0.96)$ & $(0.19)$ & $(0.00)^{* * *}$ & $(0.15)$ & $(0.59)$ & $(0.00)^{* * * *}$ & $(0.00)^{* * * *}$ & $(0.00)^{* * * *}$ & $(0.38)$ & $(0.00)^{* * *}$ & $(0.00)^{* * *}$ \\
\hline \multirow{2}{*}{ Hong Kong } & Hang Seng & -0.00024 & -0.10243 & 0.71656 & \begin{tabular}{|l|}
-0.00118 \\
\end{tabular} & -0.00687 & 0.00549 & $\mid-0.01109$ & -0.01906 & 0.00128 & 0.00044 & 0.00002 & 0.00025 & 0.00047 & 0.00551 & \begin{tabular}{|c|}
-0.00169 \\
\end{tabular} & 0.01049 & \begin{tabular}{|l|}
0.00422 \\
\end{tabular} & -0.01864 & 0.05536 & \begin{tabular}{|l|}
-0.01791 \\
\end{tabular} & 0.02517 & 0.18468 \\
\hline & Index & $(0.71)$ & $(0.00)^{* * *}$ & $(0.00)^{* * *}$ & $(0.96)$ & $(0.80)$ & $(0.86)$ & $(0.67)$ & $(0.43)$ & $(0.18)$ & $(0.64)$ & $(0.98)$ & $(0.79)$ & $(0.82)$ & $(0.00)^{* * *}$ & $(0.02)^{* *}$ & $(0.00)^{* * *}$ & $(0.00)^{* * * *}$ & $(0.00)^{* * * *}$ & $(0.00)^{* * * *}$ & $(0.00)^{* * * *}$ & $(0.00)^{* * *}$ & $(0.00)^{* * *}$ \\
\hline \multirow[t]{2}{*}{ India } & Bombay & -0.00026 & 0.46731 & 0.21858 & \begin{tabular}{|l|}
-0.00099 \\
\end{tabular} & -0.01876 & -0.00962 & 0.03504 & -0.00598 & 0.00120 & 0.00055 & 0.00117 & 0.00022 & 0.00374 & \begin{tabular}{|l|}
-0.01628 \\
\end{tabular} & \begin{tabular}{|l|}
0.01034 \\
\end{tabular} & -0.00054 & -0.03093 & 0.03673 & 0.01241 & \begin{tabular}{|l|}
-0.02207 \\
\end{tabular} & 0.01038 & 0.112754 \\
\hline & Sensex & $(0.70)$ & $(0.00)^{* * *}$ & $(0.00)^{* * *}$ & $(0.96)$ & $(0.37)$ & .61) & .11) & $(0.80)$ & $(0.23)$ & $(0.56)$ & $(0.20)$ & $(0.81)$ & $(0.11)$ & $(0.00)^{* * *}$ & $(0.00)^{* * *}$ & $(0.51)$ & $(0.00)^{* * * *}$ & $(0.00)^{* * *}$ & $(0.00)^{* * *}$ & $(0.00)^{* * * *}$ & $(0.00)^{* * *}$ & $(0.00)^{* * * *}$ \\
\hline \multirow[t]{2}{*}{ Indonesia } & Jakarta & 0.00127 & -0.02970 & 0.34549 & \begin{tabular}{|l|}
0.13045 \\
\end{tabular} & -0.00428 & 0.01862 & \begin{tabular}{|l|}
-0.02098 \\
\end{tabular} & 0.01449 & 0.00054 & -0.00263 & -0.00068 & -0.00124 & 0.00190 & 0.00665 & \begin{tabular}{|l|}
-0.00297 \\
\end{tabular} & 0.00138 & \begin{tabular}{|l|}
0.00697 \\
\end{tabular} & -0.02528 & 0.02318 & \begin{tabular}{|l|}
-0.04213 \\
\end{tabular} & -0.03023 & 0.066462 \\
\hline & Comps & $26)^{*}$ & $(0.41)$ & $(0.00)^{* * *}$ & $(0.00)^{* * *}$ & $(0.85)$ & $(0.42)$ & $(0.41)$ & $(0.57)$ & $(0.58)$ & $(0.01)^{* * *}$ & $(0.47)$ & $(0.20)$ & $(0.34)$ & $(0.00)^{* * *}$ & $(0.00)^{* * *}$ & $(0.06)^{*}$ & $(0.00)^{* * * *}$ & $(0.00)^{* * *}$ & $(0.00)^{* * *}$ & $(0.00)^{* * *}$ & $(0.00)^{* * *}$ & $(0.00)^{* * *}$ \\
\hline \multirow[t]{2}{*}{ Japan } & Nikkei 225 & -0.00063 & 0.47458 & 0.67187 & \begin{tabular}{|l|}
-0.19337 \\
\end{tabular} & -0.00880 & -0.01782 & -0.00005 & 0.02319 & 0.00036 & 0.00089 & 0.00035 & 0.00049 & -0.00130 & -0.01156 & 0.01382 & 0.00164 & \begin{tabular}{|l|}
-0.01096 \\
\end{tabular} & 0.00526 & 0.00721 & \begin{tabular}{|l|}
0.00746 \\
\end{tabular} & -0.02291 & 0.334759 \\
\hline & Nihon K & $(0.22)$ & $(0.00)^{* * *}$ & $(0.00)^{* * *}$ & $(0.00)^{* * * *}$ & $(0.67)$ & $(0.41)$ & $(0.99)$ & $(0.25)$ & $(0.61)$ & $(0.25)$ & $(0.62)$ & $(0.49)$ & $(0.41)$ & $(0.00)^{* * * *}$ & $(0.00)^{* * *}$ & $(0.02)^{* *}$ & $(0.00)^{* * *}$ & $(0.00)^{* * *}$ & $(0.00)^{* * *}$ & $(0.00)^{* * * *}$ & $(0.00)^{* * *}$ & $(0.00)^{* * *}$ \\
\hline \multirow[t]{2}{*}{ Korea } & \begin{tabular}{|l|} 
KOSPI Korea \\
\end{tabular} & 0.00022 & 0.48920 & 0.53462 & \begin{tabular}{|l|}
-0.05886 \\
\end{tabular} & -0.00125 & 0.00495 & \begin{tabular}{|l|}
-0.01539 \\
\end{tabular} & -0.01748 & -0.00006 & -0.00005 & 0.00042 & 0.00032 & $\begin{array}{ll}0.00652 \\
\end{array}$ & \begin{tabular}{|l|}
-0.01835 \\
\end{tabular} & -0.00768 & -0.00148 & \begin{tabular}{|l|}
-0.02899 \\
\end{tabular} & -0.01478 & 0.02244 & \begin{tabular}{|l|}
0.01095 \\
\end{tabular} & -0.03993 & 0.163925 \\
\hline & Composite & $(0.75)$ & $(0.00)^{* * *}$ & $(0.00)^{* * *}$ & $(0.00)^{* * *}$ & $(0.94)$ & $(0.82)$ & $(0.42)$ & $(0.45)$ & $(0.95)$ & $(0.96)$ & $(0.68)$ & $(0.74)$ & $(0.04)^{* *}$ & $(0.00)^{* * *}$ & $(0.00)^{* * *}$ & $(0.07)^{*}$ & $(0.00)^{* * *}$ & $(0.00)^{* * *}$ & $(0.00)^{* * *}$ & $(0.00)^{* * * *}$ & $(0.00)^{* * *}$ & $(0.00)^{* * *}$ \\
\hline \multirow[t]{2}{*}{ Malaysia } & Kuala & 0.00054 & -0.02977 & 0.21174 & 0.00668 & 0.04497 & 0.04620 & -0.10734 & 0.07338 & 0.00002 & -0.00156 & -0.00027 & 0.00031 & -0.00139 & -0.00194 & -0.00522 & 0.00252 & $\begin{array}{l}0.00941 \\
\end{array}$ & -0.00418 & -0.00620 & 0.00011 & -0.00354 & 0.040016 \\
\hline & ne & (0.) & $(0.39)$ & $(0.00)^{* * *}$ & $(0.91)$ & $(0.16)$ & $(0.07)^{*}$ & $(0.16)$ & $(0.13)$ & $(0.96)$ & $(0.02)^{* *}$ & $(0.77)$ & $(0.63)$ & $(0.51)$ & $(0.01)^{* *}$ & $(0.00)^{* * *}$ & $(0.00)^{* * *}$ & $(0.00)^{* * * *}$ & $(0.07)^{*}$ & $(0.00)^{* * *}$ & $(0.95)$ & $(0.06)^{*}$ & $(0.00)^{* * *}$ \\
\hline Philippines & & 0.00027 & 0.17239 & 0.52093 & \begin{tabular}{|l|}
0.08918 \\
\end{tabular} & -0.01421 & -0.01820 & 0.01998 & -0.02643 & -0.00028 & -0.00126 & 0.00002 & 0.00066 & 0.00047 & \begin{tabular}{|l|}
-0.01382 \\
\end{tabular} & 0.02550 & -0.00621 & \begin{tabular}{|l|}
-0.01393 \\
\end{tabular} & 0.01376 & -0.00089 & \begin{tabular}{|l|}
-0.04375 \\
\end{tabular} & -0.02167 & 0.184911 \\
\hline & Compo & $(0.65)$ & $(0.00)^{* * *}$ & $(0.00)^{* * *}$ & $(0.00)^{* * * *}$ & $(0.46)$ & $(0.43)$ & $(0.33)$ & $(0.17)$ & $(0.73)$ & $(0.10)^{*}$ & $(0.97)$ & $(0.35)$ & $(0.81)$ & $(0.00)^{* * * *}$ & $(0.00)^{* * *}$ & $(0.00)^{* * *}$ & $(0.00)^{* * *}$ & $(0.00)^{* * *}$ & $(0.24)$ & $(0.00)^{* * * *}$ & $0.00)^{* * *}$ & $(0.00)^{* * *}$ \\
\hline Singapore & Straits Times & 0.00083 & 0.48858 & 0.35526 & \begin{tabular}{|l|}
-0.02744 \\
\end{tabular} & 0.02519 & 0.01849 & 0.00489 & -0.01036 & 0.00153 & -0.00099 & -0.00032 & -0.00078 & 0.00139 & \begin{tabular}{|l|}
0.00087 \\
\end{tabular} & 0.00931 & 0.00239 & -0.02005 & 0.02560 & -0.00427 & -0.01869 & 0.00620 & 0.217533 \\
\hline & Index & $(0.08)^{*}$ & $(0.00)^{* * *}$ & $(0.00)^{* * *}$ & $(0.40)$ & $(0.30)$ & $(0.43)$ & $(0.80)$ & $(0.65)$ & $(0.04)^{* *}$ & $(0.16)$ & $(0.64)$ & $(0.27)$ & $(0.57)$ & $(0.19)$ & $(0.00)^{* * * *}$ & $(0.00)^{* *}$ & $(0.00)^{* * *}$ & $(0.00)^{* *-}$ & $(0.00)^{* * *}$ & $(0.00)^{* * * *}$ & $0.00)^{* * *}$ & $(0.00)^{* * *}$ \\
\hline Taiwan & TTiwn & 0.00065 & 0.30318 & 0.39537 & $\mid-0.03594$ & 0.04601 & 0.02944 & -0.06235 & 0.00922 & -0.00174 & -0.00129 & -0.00006 & -0.00067 & 0.00319 & -0.01455 & 0.01271 & 0.00001 & \begin{tabular}{|l}
-0.01226 \\
\end{tabular} & 0.02523 & 0.00316 & \begin{tabular}{|l|}
-0.03710 \\
\end{tabular} & -0.03311 & 0.136533 \\
\hline & Weighted & $(0.22)$ & $(0.00)^{* * *}$ & $(0.00)^{* * *}$ & $(0.04)^{* * *}$ & $(0.02)^{* *}$ & $(0.12)$ & $(0.00)^{* * *}$ & $(0.64)$ & $(0.04)^{* *}$ & $(0.11)$ & $(0.93)$ & $(0.38)$ & $(0.21)$ & $(0.00)^{* * *}$ & $(0.00)^{* * *}$ & $(0.98)$ & $(0.00)^{* * * *}$ & $(0.00)^{* * *}$ & $(0.00)^{* * * *}$ & $(0.00)^{* * *}$ & $(0.00)^{* * *}$ & $(0.00)^{* * *}$ \\
\hline
\end{tabular}

heteroskedasticity estimators are presented. 
Table 2 The effects of nuclear tests on Asian stock Markets. Quantile Regression estimates and estimates with GARCH modelling.

\begin{tabular}{|c|c|c|c|c|c|c|c|c|c|c|c|c|c|c|c|c|c|c|c|c|c|c|c|c|}
\hline \multirow[t]{2}{*}{ country } & \multirow[t]{2}{*}{ Stock Index } & \multirow[t]{2}{*}{ Estimation } & \multirow[t]{2}{*}{$v_{0}$} & \multirow[t]{2}{*}{$\mathrm{RW}_{\mathrm{t}}$} & \multirow[t]{2}{*}{$\mathbf{R W}_{t-1}$} & \multirow[t]{2}{*}{$\mathbf{R}_{t-1}$} & \multirow[t]{2}{*}{$R_{t: 2}$} & \multirow[t]{2}{*}{$R_{t-3}$} & \multirow[t]{2}{*}{$R_{t-4}$} & \multirow[t]{2}{*}{$\mathbf{R}_{t-5}$} & \multirow[t]{2}{*}{ Mon. } & \multirow[t]{2}{*}{ Tues. } & \multirow[t]{2}{*}{ wed. } & \multirow[t]{2}{*}{ Thurs. } & \multirow[t]{2}{*}{$\left|\begin{array}{c}\text { First } 5 \\
\text { days of } \\
\text { tax year }\end{array}\right|$} & \multicolumn{3}{|c|}{\begin{tabular}{|c|}
$\begin{array}{c}\text { Post Nuclear Test } \\
\text { Announcement (03/10/2006) }\end{array}$ \\
\end{tabular}} & \begin{tabular}{|r} 
Pos \\
Announc
\end{tabular} & $\begin{array}{l}\text { st Nuclear } \\
\text { cement (25 }\end{array}$ & $\begin{array}{l}\text { Test } \\
\text { T/o5/2009) } \\
\end{array}$ & \begin{tabular}{|c} 
Lehman \\
De \\
Annour
\end{tabular} & $\begin{array}{l}\text { Brothers } \\
\text { fault } \\
\text { ncement }\end{array}$ & \\
\hline & & & & & & & & & & & & & & & & & & & & & & & & $\begin{array}{l}\text { statistic } \\
\text { (p-value) }\end{array}$ \\
\hline hina & & Basic Model & 0.001023 & 0.09297 & \begin{tabular}{|c|}
0.142828 \\
\end{tabular} & \begin{tabular}{|l|}
-0.00859 \\
\end{tabular} & -0.05408 & 0.0268 & 0.029272 & -0.02612 & $5.61 E-05$ & 0.000338 & 0.000274 & \begin{tabular}{|c|}
-0.00107 \\
\end{tabular} & \begin{tabular}{|l|l|}
0.005773 \\
\end{tabular} & \begin{tabular}{|l|l}
-0.00175 \\
\end{tabular} & 0.00203 & \begin{tabular}{|c|}
-0.00132 \\
\end{tabular} & \begin{tabular}{|l|l|}
-0.0106 \\
\end{tabular} & 0.01478 & -0.00005 & -0.00263 & 0.04035 & \begin{tabular}{|l|l|l|}
0.013974 \\
\end{tabular} \\
\hline & & & 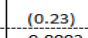 & $(0.00)^{* * * 1}$ & $(0.00)^{* * *}$ & - & $(0.02)^{* *-1}$ & & & & (0.96) & 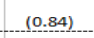 & 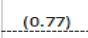 & s. & $(0.07)^{*}$ & $(0.022)=$ & $(0.05$ & & $(0.00)^{*}=1.6$ & $0.00)^{* * * *}$ & 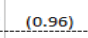 & & & $(0.00)^{* * *}$ \\
\hline & & \begin{tabular}{|l} 
Quantile \\
Regression
\end{tabular} & -0.0003 & 0.0400 & 0.0961 & \begin{tabular}{|c|c|}
-0.0219 \\
\end{tabular} & -0.0161 & 0.0475 & 0.0209 & -0.0117 & 0.0010 & 0.0012 & 0.0009 & -0.0001 & 0.0019 & -0.0012 & -0.0005 & -0.0001 & -0.0089 & 0.0154 & 0.0007 & -0.0018 & 0.0413 & \\
\hline long Kong & & $\frac{\mid(t=0.50)}{\text { Basic Model }}$ & \begin{tabular}{|l|l|}
$0.5053)$ \\
0.000348
\end{tabular} & $\frac{(0.15)}{-0.09013}$ & $\mid$ & \begin{tabular}{|l|}
0.025290 \\
0.0250
\end{tabular} & $\frac{(0.43)}{-0.01761}$ & $\frac{\mid 0.00)^{2 x+2 x}}{0.038782}$ & \begin{tabular}{|c|c|}
$(0.26)$ \\
-0.01187
\end{tabular} & $\frac{(0.53)}{-0.00615}$ & \begin{tabular}{|l|}
0.199 \\
0.000374
\end{tabular} & $\frac{(0.08)^{*}}{0.0035}$ & $0.211)$ & $\mid$ & \begin{tabular}{|l|} 
\\
\end{tabular} & $(0.66)$ & (0.84) & \begin{tabular}{|c} 
\\
\end{tabular} & $(0.00)^{* * *}$ & $(0.00)^{* * *}$ & (0.78) & \begin{tabular}{|l|}
$(0.56)$ \\
\end{tabular} & $0.00)^{* * *}$ & \\
\hline & Sen & & & $(0.00)^{* * * *}$ & 0.0 & & & & & soute & 0.000374 & 0.000352 & -0.00042 & -0.00049 & 0.000319 & $\mid \begin{array}{l}0.005251 \\
(1)=* *\end{array}$ & 0.00119 & 0.010832 & 0.00375 & -0.01675 & .055296 & -0.0137 & .02020889 & $\mid \begin{array}{l}0.181481 \\
.\end{array}$ \\
\hline & & Quantile & 0.0001 & -0.0684 & 0.5947 & 0.0001 & -0.0182 & 0.0285 & -0.0041 & -0.0072 & 0.0007 & 0.0004 & -0.0002 & 0.0000 & $\begin{array}{l}0.0006 \\
\end{array}$ & 0.0051 & -0.0015 & 0 & 0.0031 & -0.0167 & 0.0549 & $\begin{array}{l}-0.0144 \\
\end{array}$ & 0.0206 & 0.00 \\
\hline & & $\begin{array}{l}\text { ress } \\
\text { o.s. }\end{array}$ & & $(0.04)^{* *}$ & $(0.00)^{* * *}$ & & & & & & & & & & & $(0.04)=*$ & & $0.00)^{*=}$ & & $.00)^{* t=t}$ & .00) $=1=$ & & & \\
\hline dia & nbay & Basic Model & \begin{tabular}{|l|l|}
0.00087 \\
\end{tabular} & 0.370478 & 0.230134 & 0.018492 & 0.006724 & -0.00062 & 0.035283 & -0.01535 & \begin{tabular}{|l|l|}
0.000979 \\
\end{tabular} & $-9.5 E-05$ & $-7.9 E-05$ & 0.000314 & 0.00099 & -0.01546 & 0.010143 & 0.00207 & 0.03 & 0.036281 & 0.011103 & 0.02515 & 0.010933 & 0.110932 \\
\hline & Inc & jw & (o. & $(0.00)^{* * *}$ & $(0.00)^{* * * *}$ & & & & $(0.09)^{*}$ & $(0.42)$ & & $(0.89)$ & (0.91) & & & $(0.00)^{* * *}$ & $(0.00)^{* * *}$ & & $.00)^{* * *}$ & $f^{* * *}$ & & & & $(0.00)^{* * * *}$ \\
\hline & & & 0.00003 & 0.3654 & 0.2064 & 0.0085 & -0.0144 & 0.0062 & 0.0240 & 0.0072 & 0.0017 & 0.0006 & 0.0003 & 0.0008 & 0.0024 & -0.0152 & 0.0105 & -0.0013 & -0.0295 & 0.0370 & 0.0119 & -0.0262 & 0.0095 & \\
\hline & & $\begin{array}{l}\text { Regression } \\
(\tau=0.50)\end{array}$ & & $(0.00)^{* \ldots *}$ & & & & & & & & & & & & & & & & & & & & \\
\hline donesia & kirarta & \begin{tabular}{|l|l|} 
Basic Model \\
with
\end{tabular} & \begin{tabular}{|l}
0.001086 \\
\end{tabular} & -0.05481 & 0.308704 & \begin{tabular}{|l|l|}
0.12917 \\
\end{tabular} & -0.00832 & 0.030294 & 0.021794 & 0.008043 & 0.001446 & -0.00257 & $\begin{array}{l}0.000174 \\
\end{array}$ & .00036 & 002068 & 0.005268 & 0.00355 & 0018 & .005819 & 0.02522 & 022359 & -0.04324 & -0.02956 & \begin{tabular}{|l|l}
0.068406 \\
\end{tabular} \\
\hline & Inde & $\begin{array}{l}\text { Adjus } \\
\text { Adn }\end{array}$ & $(0.04)^{* * *}$ & $(0.06)^{*}$ & & $(0.00) * * *$ & & & & & & $(0.00)^{* * 1 *}$ & & & & $(0.00)^{*=1}=$ & & & & & & & & . \\
\hline & & $\mid \begin{array}{l}\text { Quartiti } \\
\text { Regress }\end{array}$ & 0.0005 & -0.0177 & 0.2349 & 0.0628 & -0.0151 & 0.0324 & 0.0076 & -0.0081 & 0.0006 & -0.0015 & -0.0004 & 0.0003 & -0.0005 & 0.0060 & -0.0027 & 0.0032 & 0.0058 & -0.0216 & 0.0206 & -0.0404 & .0352 & \\
\hline & & $(\tau=0.50)$ & \begin{tabular}{|l}
$(0.34)$ \\
\end{tabular} & $(0.46)$ & $(0.00)^{* * *}$ & $(0.00)^{* * * *}$ & $(0.36)$ & $(0.04)^{* *=}$ & $(0.67)$ & $(0.58)$ & $(0.35)$ & $(0.03)^{* *}$ & $(0.57)$ & $(0.65)$ & $(0.54)$ & $(0.01)^{* * *}$ & $(0.28)$ & (0.21) & $(0.03)^{* *}$ & $(0.00)^{* * *}$ & $(0.00)^{*=1}$ & $(0.00)^{* z=}$ & $(0.00)^{* * *}$ & \\
\hline oan & Kei 225 & & \begin{tabular}{|c|c|} 
& -0.0003 \\
\end{tabular} & 0.457316 & 0.647096 & -0.17413 & 0.015992 & 0.012692 & 0.002945 & 0.026834 & 0.000377 & 0.000332 & $\mid-0.00012$ & 0.000416 & \begin{tabular}{|l|}
-0.00021 \\
\end{tabular} & $|-0.01158|$ & 0.013526 & 0.000852 & $\mid-0.01097$ & 0.006241 & 0.007191 & \begin{tabular}{|l|l|}
0.009178 \\
\end{tabular} & -0.02313 & 0.336446 \\
\hline & nc & & & 10.00 & $:=*$ & (0.0 & & & $(8)$ & & 4) & & & & & $(0.00)^{* * * *}$ & $=* *$ & & & & & & & $(0.00) * w$ \\
\hline & & $\begin{array}{l}\text { Quantile } \\
\text { Regresssion }\end{array}$ & -0.0003 & 0.4496 & 0.5722 & -0.1703 & 0.0037 & -0.0072 & -0.0002 & 0.0138 & 0.0003 & 0.0002 & -0.0002 & 0.0001 & -0.0009 & -0.0114 & 0.0148 & 0.0015 & -0.0100 & 0.0068 & 0.0062 & 0.0082 & -0.0264 & \\
\hline & & $\begin{array}{l}(\pi, t=0.50) \\
(\tau)\end{array}$ & & $(0.00)^{* * *}$ & & $(0.00)^{* * *}$ & $(0.86))$ & & & & & & & & & & & & $10.0 \mathrm{c}$ & & & & & \\
\hline orea & k & & 0.000825 & 0.502558 & 0.545697 & -0.0881 & 0.00511 & 0.009666 & 89 & 00424 & \begin{tabular}{|c|}
-0.00066 \\
\end{tabular} & 991 & 00053 & 00561 & \begin{tabular}{|c|}
-0.00031 \\
\end{tabular} & -0.01826 & -0.00929 & -0.00201 & -0.0293 & -0.01512 & 0.021717 & 0.011377 & -0.03914 & $\mid 0.165489$ \\
\hline & Price & & & & $00)^{0 * * * 1}$ & $(0.00)^{* * * *}$ & & & & 0.82) & & 21) & & & & $* *$ & & & & & & & & $(0.00)^{* * * *}$ \\
\hline & & $\mid \begin{array}{l}\text { Quantile } \\
\text { Regressi }\end{array}$ & 0.0011 & 0.4495 & 0.3781 & -0.0471 & -0.0041 & 0.0158 & -0.0178 & -0.0272 & -0.0005 & -0.0009 & .0000 & 0.0002 & 0.0003 & -0.0187 & -0.0070 & -0.0015 & -0.0278 & -0.0126 & 0.0208 & 0.0116 & -0.0458 & \\
\hline & & $\begin{array}{l}\text { Regres } \\
(\tau=0.50\end{array}$ & $(0.06)^{*}$ & $(0.00$ & & & & & & & & & & & & )$^{* * * *}$ & & & & & & & & \\
\hline alaysia & & & $-8.6 E-05$ & -0.05996 & 0.142667 & 0.154091 & 0.02332 & 0.010988 & -0.01792 & 0.007169 & \begin{tabular}{|l|l|}
0.00101 \\
\end{tabular} & -0.00062 & 00026 & \begin{tabular}{|l|}
0.000591 \\
\end{tabular} & 0.000643 & \begin{tabular}{|c|} 
\\
\end{tabular} & -0.00369 & 0.003951 & 0.007667 & -0.00469 & -0.00363 & 0.001079 & 0.00669 & 0.02645 \\
\hline & & with $\mathrm{G}$ & & & $(0.00)^{* * *}$ & $=$ & & & & & & & & & & & & & & & & & & 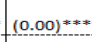 \\
\hline & & Quant: & 0.0001 & -0.0209 & 0.1984 & 0.0664 & 0 & 0 & -0.0237 & 0.0308 & 0.0003 & -0.0011 & 0.0000 & -0.0001 & -0.0001 & 21 & -0.0044 & 0.0035 & 0.0079 & 54 & 38 & 0.0008 & & \\
\hline lippi & & & & & & $(0.02)^{* *}$ & (1).1.57) & $(0.13)$ & $(0.36)$ & 20. & & 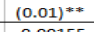 & & & 78 & & & $(0.03)^{* * *}$ & $(0.00)^{* * * *}$ & $* * *$ & 3) $* *$ & 68) & 6) $)^{*}$ & \\
\hline sm & PSE Composite & & 0.00082 & 0.138753 & 0.511678 & & 0.012385 & & 0.024651 & -0.01472 & $\mid-0.00098$ & 55 & -0.00031 & & 0.001748 & $\begin{array}{l}-0.01386 \\
-0.196\end{array}$ & 6645 & & & & & & & 187876 \\
\hline & & $\begin{array}{l}\text { Adus } \\
\text { Quant } \\
\text { Quant }\end{array}$ & -0.0001 & 0.1102 & 0.4175 & 0.0585 & -0.0376 & 0.0029 & 0 & $\begin{array}{l}-0.0259 \\
-0.0259\end{array}$ & -0.0007 & 09 & 0.00 & 0.0 & 0.0000 & - & 0.0261 & 47 & -0.0128 & 0.0153 & 510 & -0.0441 & & 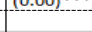 \\
\hline & & 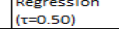 & & & & & & $(0.88)$ & & & & & & & & (o. & & & & & & & & \\
\hline zapore & & $\begin{array}{l}\text { Basic Model } \\
\text { With Garch }\end{array}$ & \begin{tabular}{|l|l|}
0.000829 \\
\end{tabular} & 0.444513 & \begin{tabular}{|l|}
0.39111 \\
\end{tabular} & \begin{tabular}{|l|l|}
-0.07806 \\
\end{tabular} & 0.007822 & 0.025691 & 0.023259 & 0.009748 & -0.00095 & -0.00123 & -0.00078 & & 0.003944 & \begin{tabular}{|l|l|} 
\\
\end{tabular} & 0.00956 & 0.002529 & \begin{tabular}{|l|l|}
-0.01904 \\
\end{tabular} & 0.02 & -0.00233 & -0.02189 & 0.006808 & \begin{tabular}{|l|}
0.21731 \\
\end{tabular} \\
\hline & & & & & & & & & & & & & & & & & & & & & & & & $(0.00)^{* * *}$ \\
\hline & & & 0.0006 & 0.4171 & & -0.8 & 08 & & 0 & 0 & -0.0011 & -0.0011 & -0.0001 & -0.0006 & 0.0011 & 10 & 0.0097 & 0.0030 & -0.0181 & 0.0250 & -0.0032 & -0.0217 & 0.0054 & \\
\hline & & & 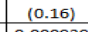 & $(0.0$ & & & $(0.007)$ & & & & & & 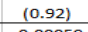 & & 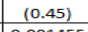 & & & $=(0.16)$ & $(0.00)^{* * * *}$ & & & 1):** & $(0.04)^{* *}$ & 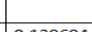 \\
\hline aiwan & \begin{tabular}{|c} 
Taiwan \\
weighted Index
\end{tabular} & & | 0.0009339 & 0.318967 & & -0.03612 & 0.027234 & 0.02964 & -0.03361 & & -0.00116 & -0.00167 & -0.00059 & -0.00075 & |0.001455 & -0.0139 & 0.01231 & 00088 & $\mid-0.01263$ & 25123 & 0.002825 & .0374 & 197 & 0.139694 \\
\hline & & Quar & 0.0005 & 0.2635 & 0.3546 & -0.0515 & 0.02 & 0.0099 & 0.0 & -1 & -0.0006 & -0.001 & -0.0003 & -0.0 & 0003 & 0136 & 0.131 & & 0.0114 & & & & -0.0365 & $\because$ \\
\hline & & 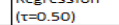 & $(0.36)$ & $(0.00)^{* \cdots}$ & $(0.00)^{* \cdots}$ & $(0.00)^{* * * *}$ & $(0.26)$ & .54) & $(0.00)^{* * *}$ & $(0.87)$ & $(0.41)$ & $(0.12)$ & $(0.67)$ & $0.49)$ & 0.83 & $(0.00)^{* \ldots *}$ & $(0.00)^{* \cdots *}$ & $(0.93)$ & $(0.00)^{* * *}$ & $(0.00)^{* * *}$ & $(0.21)$ & $(0.00)^{n \ldots}$ & $(0.00)^{* \cdots}$ & \\
\hline
\end{tabular}

Notes: $* * *, * * *$ statistically significant at the $1 \%, 5 \%$ and $10 \%$ level; p-value of z-statistics in parentheses $(\cdot)$. For the GARCH model estimation, since the

innovations appear leptokurtic rather than normally distributed, quasi-maximum likelihood (QML) covariances and robust standard errors have been used (see

Bollerslev, Wooldridge, 1992). 
Figure1: The effect of the nuclear tests on foreign exchange markets

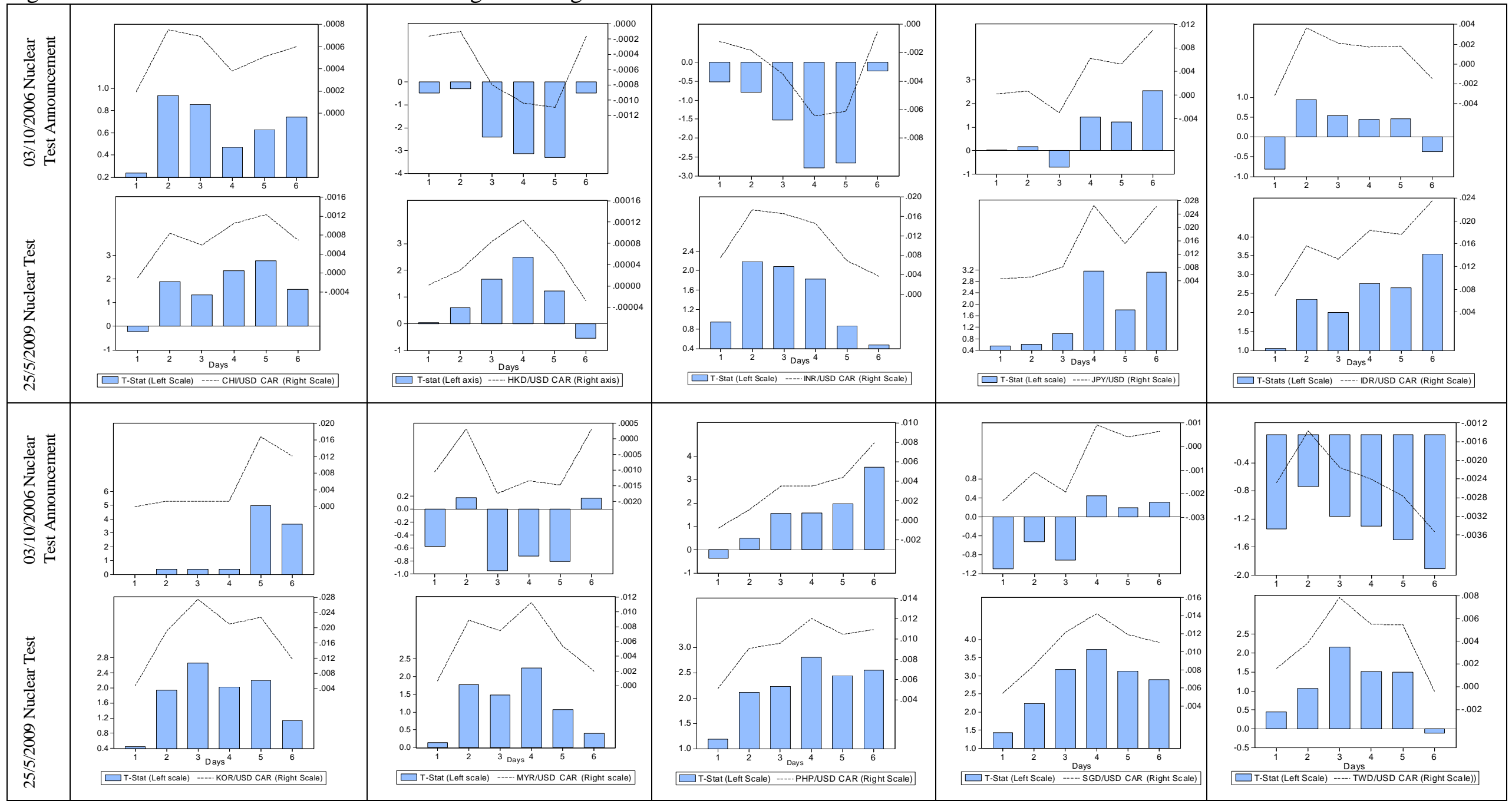

